Rafał M. Antoszczuk OFMConv, Zakrystia jako przestrzeń przygotowania do liturgii na przykładzie zakrystii bazyliki św. Franciszka z Asyżu w Krakowie, w: Przestrzeń liturgiczna, red. Adelajda Sielepin CHR, Jarosław Superson SAC, Kraków 2019, s. 165-179.

DOI: http://dx.doi.org/10.15633/9788374387828.08

Rafał M. Antoszczuk OFMConv

Uniwersytet Papieski Jana PaWla II w Krakowie

\title{
Zakrystia jako przestrzeń przygotowania do liturgii na przykładzie zakrystii bazyliki św. Franciszka z Asyżu w Krakowie
}

Wiele razy w trakcie przygotowań jakichś ważnych wydarzeń religijnych, państwowych czy kulturalnych znajdują się osoby zainteresowane samymi przygotowaniami tych wydarzeń. Często wtedy pada, funkcjonujące w języku polskim powiedzenie: „Chciałbym zobaczyć to od zakrystii”, tzn. zobaczyć coś od zaplecza, coś co nie jest widoczne dla widza, który przychodzi na spektakl. Przytoczone tu powiedzenie ma swoje źródło w świętej przestrzeni, która obecna jest w każdym kościele czy kaplicy, jednak nie zawsze dostępna dla ludzkiego oka. Nie ma bowiem świątyni, która by nie miała miejsca oddzielonego od przestrzeni liturgicznej, służącego do bezpośredniego przygotowania do celebracji liturgicznej na sposób duchowy, ale i techniczny. To miejsce to zakrystia, która dla wielu ludzi jest owiana swoistą tajemnicą, a ich wejście w tę tajemnicę wiąże się przeżywaniem stresu, szczególnie w momentach załatwiania spraw z duszpasterzem lub zamawiania intencji mszalnej. Tymczasem od wieków zakrystia była miejscem nie tylko przechowywania Świętych Postaci czy paramentów liturgicznych, ale miejscem wyciszenia i modlitwy przygotowujących się do celebracji. Szkoda, że dziś wielu duszpasterzy, projektując zakrystie, zapomina o tym i zapełnia je śmieciami, bałaganem i sprzętami, których miejsce nie jest w przestrzeni sakralnej. Zakrystia to święta część każdego kościoła czy kaplicy, a nie składzik makulatury, tandety, rzeczy znalezionych i kiczu, w którym rozkrzyczany ksiądz wraz z ministrantami i scholką próbują ustalić przebieg liturgii, zagłuszając zamawiających intencje mszalne. 
W myśl Ogólnego wprowadzenia do Mszału rzymskiego, które mówi, że: „Każdą celebrację liturgiczną należy starannie przygotować”, niniejsze opracowanie, na przykładzie zakrystii bazyliki św. Franciszka z Asyżu w Krakowie, będzie starało się wyeksponować, a tym samym odświeżyć prawdy i tradycje kościelne na temat zakrystii, jako szczególnego miejsca świątyni, potrzebnego dla właściwego duchowego i technicznego przygotowania celebracji oraz godnego przechowywania paramentów liturgicznych. Sama zaś próba wyjaśnienia symboliki dekoracji opisywanej zakrystii może przyczynić się do uwrażliwienia na piękno sztuki sakralnej, tak bardzo pomocnej w przeżywaniu świętych tajemnic wiary.

Według różnych definicji zakrystią nazywamy pomieszczenie znajdujące się w kościele, usytuowane z boku prezbiterium i z nim połączone, służące do przechowywania szat i paramentów liturgicznych oraz przygotowania kapłana z asystą do doprawiania mszy świętej i innych obrzędów. Leksykony wspominają, że zakrystie były bogato zdobione, często składały się z kilku pomieszczeń ${ }^{2}$. Bogatą historię zakrystii oraz obszerne wiadomości na temat jej przeznaczenia i urządzenia można znaleźć w Wykładzie liturgii Kościota Katolickiego autorstwa ks. Nowowiejskiego3. Badacz ten pochodzenie zakrystii w chrześcijańskich kościołach wywodzi od pomieszczeń istniejących w jerozolimskiej świątyni, w których przechowywano sprzęty i szaty potrzebne w sprawowaniu świątynnych obrzędów i rytuałów ${ }^{4}$. Autor podaje także sposób zachowywania się w zakrystii, pisze: „W zakrystii zachowuje się milczenie i budujące zachowanie nie tylko ze strony służby kościelnej, ale i duchowieństwa, które przykładem przyświecać powinno"s. Niektóre opracowania podają, że istniały kościoły, w których zakrystie umiejscowione były przy wejściach do świątyni ${ }^{6}$. Podane tu przykłady dotyczące definicji zakrystii oraz wspomnienie o źródłach, z jakich wywodzi się tradycja tego pomieszczenia i jego przeznaczenia dowodzą, że rzeczywistość istnienia w przestrzeni sakralnej zakrystii nie była i nie jest kwestią drugoplanową i mało ważną.

\footnotetext{
Ogólne wprowadzenie do Mszalu rzymskiego, Poznań 2006, II.

2 Por. Leksykon liturgii, oprac. B. Nadolski, Poznań 2006, s. I722 oraz Wielka encyklopedia $P W N$, t. 30, Warszawa 2005, s. 2II.

3 Ks. A. Nowowiejski, Wykład liturgii Kościoła Katolickiego, t. I, Warszawa I893, S. I283-I289.

4 Por. ks. A. Nowowiejski, Wyktad liturgii..., dz. cyt., s. I283.

5 Ks. A. Nowowiejski, Wyktad liturgii..., dz. cyt., s. I287.

6 Por. T. Sinka CM, Zarys liturgiki, Kraków 2006, s. I90.
} 
Bazylika św. Franciszka z Asyżu w Krakowie to świątynia wybudowana w XIII wieku przez franciszkanów, którzy do ówczesnej stolicy Polski przybyli w roku I2377. Wraz z kościołem wybudowano pomieszczenie, które przeznaczone było na zakrystię. Pomieszczenie to istnieje do dziś, choć współcześnie zorganizowana zakrystia bazyliki to dwie sale. Pierwszą stanowi sala gotycka, drugą barokowa. Sala gotycka, jak było wspomniane, powstała wraz ze świątynią franciszkańską w XIII wieku. Jest ona prostokątna, zakończona od wschodu trójboczną absydą. Jej ostrołukowe, krzyżowo-żebrowe sklepienie udekorowane jest rzeźbionymi zwornikami. Zachowane zostały także gotyckie okna oraz fragmenty średniowiecznych, renesansowych i barokowych polichromii ${ }^{8}$. W roku 1895 sklepienie zakrystii otrzymało polichromię autorstwa Franciszka Górskiego i Józefa Mikulskiego, którą w ostatnich czasach gruntownie odrestaurowano ${ }^{9}$. Pomieszczenie zachwyca swoją surowością i pełni do dziś funkcje zakrystii, w której przechowywane są w stylizowanych szafach z roku 2006, szaty i księgi liturgiczne wykorzystywane w uroczystych, dużych celebracjach. W sali tej eksponowane są także niektóre, niezwykle cenne, zabytkowe obrazy i rzeźby pochodzące ze zbiorów krakowskich franciszkanów. Sala ta jest również miejscem przygotowania modlitewnego kapłanów i posługujących podczas liturgii, o czym zaświadczają ustawione klęczniki. Jest tu ponadto obudowany i wyciszony konfesjonał, w którym mogą się spowiadać osoby niedosłyszące.

Niewielkim przesmykiem, gdzie znajduje się specjalna szafa na konsolę obsługującą nagłośnienie, obok dekoracyjnie wykonanego lawaterza, wchodzi się do drugiej sali zakrystii. Wejście to umiejscowione jest obok schodów prowadzących do pomieszczeń klasztornych, które stanowią połączenie klasztoru z zakrystią i ułatwiają zakonnikom komunikację. Wahadłowe, drewniano-szklane drzwi do drugiej sali dekoruje plastycznie rzeźbiona framuga, wykonana w I684 roku z czarnego marmuru, zwieńczona portalem

7 Por. Z. Gogola OFMConv, Przybycie franciszkanów do Krakowa ma tle historii miasta, w: , Umiłowany od wszystkiego miasta”. W 770. rocznicę przybycia franciszkanów do Krakowa (I237-2007), red. ks. A. Bruździński, Z. Gogola, Kraków 2007, s. I6-I8.

8 Por. J. Muczkowski, Kościót św. Franciszka w Krakowie, Kraków I90I, s. 25 oraz F. Solarz OFMConv, Historia bazyliki, krużganków i kaplic w zespole krakowskiego klasztoru franciszkanów, w: Krakowscy franciszkanie, red. B. Krużel, F. Solarz, Kraków 2009, s. 29, I02-I03.

9 Por. J. Muczkowski, Kościót św. Franciszka w Krakowie, Kraków I90I, s. 25 oraz F. Solarz OFMConv, Historia bazyliki, krużganków i kaplic w zespole krakowskiego klasztoru franciszkanów, w: Krakowscy franciszkanie, red. B. Krużel, F. Solarz, Kraków 2009, s. 29, I02-I03. 
z kartuszem, w którym umieszczono herb Zakonu Braci Mniejszych Konwentualnych. Sala, która dziś nazywa się „zakrystią barokową”, powstała w XV wieku i była przeznaczona na oratorium, w późniejszych wiekach urządzono w niej skarbiec kościelny, a dopiero w XVIII wieku zakrystię . $^{10}$. Na jej nazwę miało wpływ bogato zdobione wyposażenie, które zachwyca niezwykłym warsztatem snycerskim. Meble zostały wykonane w XVIII wieku przez artystów: Sebastiana Łagowskiego, Wojciecha Rojowskiego i Marcina Ture ${ }^{\text {II }}$. Polichromię sklepienia zakrystii wykonali w roku I897 Józef Mikulski i Franciszek Górski pod kierunkiem Stanisława Wyspiańskiego, natomiast postacie św. Franciszka i św. Klary wykonał Władysław Rossowski ${ }^{12}$. W XVIII-wiecznych, profilowanych, bogato zdobionych szafach i szufladach komód przechowywane są kielichy, pateny, cyboria, monstrancje, relikwiarze, bielizna kielichowa i ołtarzowa, a także ornaty, stuły, alby, kapy, księgi liturgiczne oraz rytuały. W tej części zakrystii przechowuje się również oleje święte, wodę święconą, wino mszalne i komunikanty. Niektóre szuflady mieszczą też sprzęty techniczne, takie jak: mikrofony, przewody elektroniczne, narzędzia potrzebne do drobnych napraw oraz różne materiały dekoracyjne. W zabytkowych komodach znajdują się ponadto szuflady dla kapłanów, w których każdy z nich przechowuje swoją bieliznę kielichową $\mathrm{i}$ inne przedmioty i sprzęty pomagające sprawować liturgię. Sam fakt, że dla godnego przechowywania paramentów liturgicznych, dla przygotowania liturgii i do liturgii projektuje się i tworzy taką oprawę, powinien każdemu uświadamiać, że liturgia to czas, miejsce i rzeczywistość celebrowania tajemnic wiary, a nie jedynie odprawiania - nawet pobożnych - modlitw. To niezwykłe wyposażenie zakrystii stanowi swoistą całość i wskazuje na ważność przygotowania liturgii. Rozbudowane zaplecki komód, szaf narożnikowych, tworzące boazerię zabudowującą trzy ściany zakrystii aż do sklepienia, wraz $\mathrm{z}$ innymi elementami całego ciągu drewnianej dekoracji, stanowią nie tylko przykład wysokiej klasy warsztatu snycerskiego, ale i niezwykły przykład dydaktycznej funkcji sztuki chrześcijańskiej. Pomaga ona, w tym przypad$\mathrm{ku}, \mathrm{w}$ teologicznym i duchowym przygotowaniu kapłana i posługujących do sprawowania liturgii i w uświadomieniu powagi świętych czynności,

\footnotetext{
Io Por. D. Biedrońska, Dokumentacja konserwatorska wystroju i wyposażenia zakrystii nowej w Bazylice OO. Franciszkanów pw. św. Franciszka z Asyżu przy Placu Wszystkich Świętych w Krakowie, Kraków 20II-20I2, s. 7.

II Por. J. Muczkowski, Kościół św. Franciszka..., dz. cyt., s. 25 oraz H. Górski, Bazylika OO. Franciszkanów, Kraków 2002, s. 2I i 30.

I2 Por. H. Górski, Bazylika OO. Franciszkanów, Kraków 2002, s. 2I i 30.
} 
miejsca i czasu. Kontemplując bowiem dekorację wnętrza tego pomieszczenia, kapłan mógł i może do dziś odbyć niezwykle odnawiającą, oczyszczającą i pouczającą podróż serca i ducha.

Dzięki umiejscowieniu drzwi do tej sali na wschodniej ścianie, w północnej jej części, uwaga kapłana wchodzącego do jej wnętrza niemal naturalnie ukierunkowana jest na ścianę południową. Dzięki umieszczonym na zapleckach komód prostokątnym obrazom, ozdobionym profilowanymi, w części złoconymi ramami, można stwierdzić, że ściana ta to ściana Starego Testamentu, ściana ofiary.

W centralnej części tej ściany, na dekoracyjnej boazerii widnieje obraz Wąż miedziany ${ }^{13}$. Jest to scena ilustrująca wydarzenie opisane w Księdze Liczb (por. 20, 4-9), z czasu wędrówki Narodu Wybranego do Ziemi Obiecanej, podczas której Pan Bóg ukarał zbuntowanych Izraelitów plagą węży, które kąsając buntowników, doprowadzały do ich śmierci. Na prośbę Mojżesza Bóg zapobiegł totalnej zagładzie. Wypełniając nakaz Boga, Mojżesz zrobił węża z miedzi i umieścił go na drewnianym palu tak, aby każdy, kto popatrzył na niego, został uzdrowiony. Wydarzenie to jest starotestamentalnym proroctwem, figurą mesjańską, zapowiadającą ofiarę zbawczej męki i śmierci Mesjasza na krzyżu' ${ }^{14}$. Mówi także o prawdzie, że każdy jest uzdrowiony z zarazy grzechu i śmierci dzięki ofierze Chrystusa ${ }^{15}$. Sam Pan Jezus w Ewangelii wg św. Jana porównuje siebie do wywyższonego węża miedzianego (por. 3, I4-I5), mówiąc także o zbawiennych tego skutkach ${ }^{16}$. Jest to zarazem symbol triumfu Bożego miłosierdzia oraz wskazówka, że nawet jeśli Bóg karze zbuntowanych, to nigdy nie pozostawia człowieka samego, zawsze pomaga w nawracaniu, by wypełnić swoje plany ${ }^{17}$.

Kapłan, przygotowując się do celebracji Najświętszej Eucharystii, wpatrując się w ten obraz, uświadamiał sobie prawdę, że zawsze należy mieć oczy wzniesione do Boga, bo tylko On ma moc uzdrawiania ${ }^{18}$. Kontemplował ukrzyżowanego Chrystusa, którego jest sługą i któremu winien posłuszeństwo w wykonywaniu Jego poleceń. Zyskiwał też świadomość, że nie własną mocą sprawuje święte czynności, ale dzięki Bożej mocy i Bożemu wybraniu.

\footnotetext{
I3 Por. D. Biedrońska, Dokumentacja konserwatorska..., dz. cyt., s. 8.

${ }^{14}$ Por. M. Lurker, Słownik obrazów i symboli biblijnych, Poznań I989, s. 257.

15 Por. S. Kobielus, Bestiarium chrześcijańskie. Zwierzęta w symbolice i interpretacji, Warszawa 2002, s. 326.

I6 Por. S. Kobielus, Bestiarium chrześcijańskie..., dz. cyt., s. 326.

17 Por. X. Leon-Dufour, Stownik teologii biblijnej, Poznań I994, s. 839.

I8 Por. D. Forstner, Świat symboliki chrześcijańskiej, Warszawa 200I, s. 307.
} 
Po lewej stronie umieszczony został obraz Ofiara Melchizedeka ${ }^{19}$ zainspirowany sceną z Księgi Rodzaju (por. I4, I7-2I), w której to Melchizedek, król Salemu i kapłan, wynosi chleb i wino na powitanie Abrahama i jego wojska po wygranej bitwie nad Kedorlaomerem i wysławiając Boga, błogosławi Abrahama. Obecnie każdy kapłan, stojąc pod graficznie ukazanym proroctwem o zbawczej męce Chrystusa, w znaku miedzianego węża, wpatruje się w postać króla Salemu i słyszy w sercu słowa Psalmu IIo: „Tyś Kapłanem na wieki na wzór Melchizedeka". Melchizedek jest figurą Mesjasza i wzorem doskonałego kapłana ${ }^{20}$. W Nowym Testamencie autor Listu do Hebrajczyków, porównując kapłaństwo Mesjasza do kapłaństwa Melchizedeka, wyraża prawdę, że Jego kapłaństwo jest doskonałe i ponadczasowe (por. 7, I-28). Ofiara z chleba i wina, jaką złożył Melchizedek, jest natomiast zapowiedzią Ofiary eucharystycznej. Zatem każdy kapłan winien pamiętać, że dar, jaki otrzymał od Boga, winien być rozwijany, a obowiązki, jakie $\mathrm{z}$ tego wynikają, powinny być spełniane z największą starannością w duchu uwielbiania Boga, dziękczynienia i błogosławienia. Potwierdza to słowami modlitwy: „[...] i dziękujemy, że nas wybrałeś, abyśmy stali przed Tobą i Tobie służyli”’2.

Po prawej stronie umieszczony został obraz Ofiara z Izaaka ${ }^{22}$. To z kolei scena z Księgi Rodzaju, która mówi o próbie, jaką poddał Bóg Abrahama, który miał złożyć ofiarę ze swojego jedynego syna, i o głębokim zaufaniu Bogu i wierze w Niego, aż po złożenie wielkich ofiar w swoim życiu. W składanej ofierze z Izaaka upatruje się także obraz ofiary Chrystusa ${ }^{23}$. Abraham, dzięki wierze Bogu i w Jego obietnice, stał się ojcem wiary wszystkich ludzi (Rdz 22, I-I9). Kapłan, kontemplując ten obraz, uzmysławiał sobie, że to on dziś ma stawać się ojcem wiary, tym, który Bogu ma składać ofiarę już nie z syna ludzkiego, ale z Syna Bożego. Uzmysławia sobie, że ma być zawsze gotowy do składania Ofiary ${ }^{24}$. Scena ta przypomina także prawdę o tym, że każdy kapłan winien Bogu ofiarowywać wszystko to, kim jest, i to, co posiada, i w ten sposób jednoczyć się z Chrystusem ${ }^{25}$.

\footnotetext{
19 Por. D. Biedrońska, Dokumentacja konserwatorska..., dz. cyt., s. 8.

20 Por. X. Leon-Dufour, Stownik..., dz. cyt., s. 466.

${ }_{21}$ Z II modlitwy eucharystycznej.

22 Por. D. Biedrońska, Dokumentacja konserwatorska..., dz. cyt., s. 8.

23 Por. D. Forstner, Świat symboliki..., dz. cyt., s. 3I4.

24 Por. D. Forstner, Świat symboliki..., dz. cyt., s. 3I4

25 Por. D. Forstner, Świat symboliki..., dz. cyt., s. 3I4.
} 
Można zadać pytanie: Czy kontemplując dekorację tej części zakrystii, kapłan przygotowujący się do sprawowania Najświętszej Ofiary nie słyszy już w sercu słów, które za moment będzie wypowiadał w Kanonie mszy świętej? Pierwsza modlitwa eucharystyczna bowiem to także błaganie skierowane do Boga, by wejrzał na ofiarę i przyjął ją: ,[...] składamy Twojemu najwyższemu majestatowi z otrzymanych od Ciebie darów Ofiarę czystą, świętą i doskonałą, Chleb święty życia wiecznego i Kielich wiekuistego zbawienia. Racz wejrzeć na nie z miłością i łaskawie przyjąć, podobnie jak przyjąłeś dary swojego sługi, sprawiedliwego Abla, i ofiarę naszego patriarchy Abrahama oraz tę ofiarę, którą Ci złożył najwyższy Twój kapłan Melchizedek jako zapowiedź Ofiary doskonałej”26. Wypełnienie starotestamentalnej zapowiedzi o ofierze Mesjasza dokonało się w zbawczych wydarzeniach Nowego Testamentu. Nie zapomnieli o tym twórcy dekoracji franciszkańskiej zakrystii. Warto nadmienić, że klamrą dopełniającą symbolikę tej grupy obrazów są owalne przedstawienia, sporych rozmiarów, po lewej stronie św. Bernarda z Clairvaux, a po prawej św. Ambrożego ${ }^{27}$. Pierwszy z nich wiarą w rzeczywistą, realną i substancjalną obecność Chrystusa w Eucharystii nawracał wielu ludzi ${ }^{28}$. Uczył także, że sakrament ten jest źródłem mocy w drodze, źródłem życia odkupionych i źródłem życia moralnego dla każdego ${ }^{29}$. Drugi z przedstawionych świętych uczył natomiast, że sakrament, który się przyjmuje, sprawiają słowa Chrystusa ${ }^{30}$.

Kapłan, przygotowując się do celebracji sakramentalnej, z miejsca symbolizującego Stary Testament zapowiadający przyjście Mesjasza i Jego zbawczą misję może przechodzić do centralnego miejsca zakrystii: jest nim ściana zachodnia - ściana Nowego Testamentu, ściana uniżenia. Na tak samo wykonanych, co na poprzedniej ścianie, boazeriach, umieszczono trzy obrazy. Centralny to Śmierć Pana Jezusa na krzyżu, po lewej jego stronie umieszczono Udzielanie Komunii św. apostołom przez Pana Jezusa, a po prawej stronie Pokłon pasterzy nowo narodzonemu Jezusowi ${ }^{31}$. Grupa tych obrazów, oprócz

\footnotetext{
${ }_{26}$ Z I modlitwy eucharystycznej.

27 Por. D. Biedrońska, Dokumentacja konserwatorska..., dz. cyt., s. 8.

28 Por. ks. J. Staszewski SChr, Cudowne nawrócenie Wilhelma, księcia Akwitanii, przez św. Bernarda z Clairvaux, „Msza Święta” 2008 nr 3, s. 26-27.

29 Por. M. P. Chojnacki OCist, Sacramentis ecclesiae communicare. Chrzest i eucharystia wedtug Bernarda z Clairvaux, Kraków 20II, s. 245-324.

3o Por. Eucharystia pierwszych chrześcijan. Ojcowie Kościoła nauczaja o Eucharystii, wybór i oprac. ks. M. Starowieyski, Kraków 20I4, s. I6.

$3^{\mathrm{I}} \quad$ Por. D. Biedrońska, Dokumentacja konserwatorska..., dz. cyt., s. 8.
} 
wydarzeń zbawczych, akcentuje człowieczeństwo, pokorę i uniżenie Chrystusa względem pełnienia woli Boga Ojca, ale i względem drugiego człowieka.

Jak było powiedziane, obrazem centralnym tej ściany jest Śmierć Pana Jezusa na krzyżu. Scena ukazuje ukrzyżowaną postać Chrystusa na tle ciemno zarysowanego tła, z którego wyłaniają się lekko zarysowane postaci ludzi oraz panorama miasta i otaczających gór. Autor obrazu chciał wyeksponować ukrzyżowanego Chrystusa oraz Jego samotne umieranie, składanie ofiary z siebie. O tej samotności umierania mówi sam Chrystus, modląc się: „Boże mój, Boże mój, czemuś mnie opuścił?” (Mt 27, 46 oraz Mk 15, 34). Obraz ten ukazuje doskonale prawdę, o której Kościół śpiewa w Prefacji wielkanocnej, że: „Przez ofiarę swojego ciała na krzyżu dopełnił On ofiary Starego Przymierza i oddając się za nasze zbawienie, sam stał się Kapłanem, Ołtarzem i Barankiem ofiarnym" ${ }^{2}$. Kapłan, kontemplując ten obraz, uświadamiał sobie, że składając Najświętszą Ofiarę, wraz z wiernymi przeżywa tamte zbawcze wydarzenia z Golgoty. Że nie jest to jedynie jakieś wspomnienie, znak, symbol, ale konkretna rzeczywistość, uobecnianie, które stanowi centrum życia Kościoła i kapłana ${ }^{33}$. Ta ofiara składana jest „Bogu wiecznemu, żywemu i prawdziwemu za siebie oraz za swoich bliskich, aby dostąpić odkupienia dusz swoich i osiągnąć zbawienie"34. Dzięki temu kapłan zyskuje wrażliwość na prawdę, że podobnie jak Chrystus, tak i on ma także składać ofiarę ze swojego życia, by „otrzymać obfite błogosławieństwo i łaskę"35.

Po lewej stronie Ukrzyżowania umieszczony został Pokłon pasterzy nowo narodzonemu Jezusowi. Scena ta znana jest z Ewangelii Łukasza (2, 8-2I). To właśnie pasterzom, jako pierwszym, aniołowie zwiastowali wieść o przyjściu Mesjasza, to im mówili, aby przestali się lękać, bo Bóg obdarza pokojem wszystkich, w których ma upodobanie (Łk 2, I4) oraz by udali się do miejsca Jego przyjścia na świat, by oddać Mu pokłon. Z kart Ewangelii dowiadujemy się, że pasterze tak uczynili, a kiedy oddali pokłon Nowonarodzonemu „wrócili wielbiąc i wysławiając Boga” (Łk 2, 2I). Kapłan, przygotowując się do celebrowania Eucharystii, patrząc na ten obraz, uświadamia sobie, że dzięki jego posłudze przy ołtarzu wypełnia się proroctwo Izajasza zapowiadające, że „przyjdzie Emmanuel, Bóg z nami” (Iz 7,I4; Mt I, 20-23), który mówi: „Oto Ja jestem z wami przez wszystkie dni, aż do skończenia

${ }^{32} \quad$ Z 5 Prefacji Wielkanocnej.

33 Por. Jan Paweł II, Encyklika Ecclesia de Eucharistia, Kraków 2003, I.

34 Z I modlitwy eucharystycznej.

35 Z I modlitwy eucharystycznej. 
świata" (Mt 28, 20). Kapłan ma być jak ewangeliczni pasterze, adorować Przychodzącego, brać z Niego przykład, prowadzić wszystkich drogami wiary, powinien - jak Maryja - ukazywać Przychodzącego tym, którzy do Niego przychodzą i tego pragną.

Obraz po lewej stronie ukazuje moment Ostatniej Wieczerzy, kiedy Pan Jezus udziela Komunii św. apostołom. To zobrazowanie pokory Jezusa Chrystusa podczas pierwszej mszy świętej pomaga kapłanowi zrozumieć, że jego wybranie przez Boga, składanie Najświętszej Ofiary to pokorna służba braciom na wzór Chrystusa umywającego nogi, składającego z siebie ofiarę oraz rodzielającego swoje Ciało łaknącym. Warto zauważyć, że grupa obrazów tej ściany wskazuje na oddawanie Jezusa siebie w ludzkie ręce: dokonywało się to podczas Jego narodzenia, ostatniej wieczerzy oraz podczas Jego męki.

Klamrą zamykającą symbolikę grupy obrazów nowotestamentalnych stanowią owalne przedstawienia św. Grzegorza i św. Augustyna. Święty Grzegorz między innymi nauczał, że zanim się złoży Bogu ofiarę, należy oczyścić umysł, bo ofiara ma być miła Bogu ze względu na czystość ofiarodawcy ${ }^{36}$. Święty Augustyn uczył natomiast, że człowiek, jeśli umiera dla świata, staje się ofiarą dla Boga oraz że Chrystus uczy ofiarowywać samego siebie ${ }^{37}$.

Dekoracja północnej ściany zakrystii ukazuje owoce całej historii zbawienia, które objawiają się także w historii zakonu franciszkanów - to ściana zjednoczenia. Na drewnianej boazerii, w centralnej części, umieszczony został obraz Stygmatyzacja św. Franciszka, po jego lewej stronie ukazany jest Cud objawienia Dzieciątka Jezus św. Antoniemu, a po stronie prawej Anielska mistyczna Komunia św. Bonawentury $3^{38}$. Zestawienie tych trzech obrazów nie jest jedynie przypomnieniem o mistycznych doznaniach zakonodawcy Franciszka czy świętych zakonu, lecz także ukazaniem, że kapłan i każdy uczestniczący w celebracji przenoszony jest do mistycznego świata oraz że w przyszłości ma żyć wiecznie w niebie. W Kanonie mszy kapłan modli się bowiem: ,_...] zachowaj nas od wiecznego potępienia i dołącz do grona swoich wybranych" 39 . Jak było wspomniane, w centrum tej grupy umieszczono obraz przedstawiający stygmatyzację św. Franciszka z Asyżu.

\footnotetext{
${ }^{6}$ Por. O. Kashchuk, Księga Rodzaju jako źródło duchowej inspiracji w „Moralia in Iob” św. Grzegorza Wielkiego, „Biblica et Patristica Thoriuniensia” 4 (20II), s. 356.

37 Por. św. Augustyn, De civitate Dei, Warszawa 1977, X, 6 i 20.

$3^{8}$ Por. D. Biedrońska, Dokumentacja konserwatorska..., dz. cyt., s. 8.

39 Z I modlitwy eucharystycznej.
} 
Święty otrzymał stygmaty na górze Alwernia I4 września I224 roku+. Obraz ten, podobnie jak pozostałe centralne obrazy omawianych już grup, akcentuje krzyż i mękę Chrystusa. Święty Franciszek dzięki temu, że jednoczył się z Chrystusem, otrzymał dar stygmatów. Dla każdego kapłana, który przygotowuje się w tym miejscu do celebrowania Eucharystii, jest to jasny i konkretny znak, że poprzez święte czynności jednoczy się z Chrystusem ukrzyżowanym, że podobnie jak św. Franciszek, staje się alter Christus i czyni wszystko in persona Christi ${ }^{44}$.

Po lewej stronie dekoratorzy zakrystii zamieścili obraz Cud objawienia Dzieciatka Jezus św. Antoniemu. Jest to zobrazowane wydarzenie z życia św. Antoniego Padewskiego, któremu objawiło się Dzieciatko Jezus, mówiąc, że bardzo kocha świętego ${ }^{42}$. Kapłan przygotowujący się do sprawowania Eucharystii, dzięki temu obrazowi dojść może do świadomości, że Bóg, udzielając się człowiekowi, dowodzi swojej miłości względem tych, którym się udziela. Natomiast człowiek winien na tę miłość odpowiadać swoją miłością względem Boga. Ofiara eucharystyczna jest dowodem Bożej miłości do ludzi i kapłan, celebrując ją, zawsze winien o tym pamiętać.

Po prawej stronie Stygmatyzacji widnieje obraz ukazujący Anielska mistyczna Komunię św. Bonawentury. To wydarzenie miało miejsce, kiedy młody zakonnik Bonawentura czuł się niegodny, by przyjmować codziennie Najświętszą Eucharystię. Wtedy to, podczas mszy świętej, objawił się anioł z nieba, który wziął Hostię z rąk odprawiającego mszę kapłana i udzielił młodemu zakonnikowi Komunii św., wkładając ją do ust i mówiąc przy tym, że lepiej jest Eucharystię z miłości przyjmować, niż z obawy się przed tym powstrzymywać43. Kapłanowi, który przygotowuje się do celebracji, obraz ten winien uświadamiać prawdę o jego niegodności względem sprawowania i przyjmowania Eucharystii. Prawda ta powinna przyczyniać się do ożywiania i pogłębiania ludzkiej miłości względem Boga i przyjmowania Komunii świętej.

40 Por. Tomasz z Celano, Życiorys pierwszy Świętego Franciszka z Asyżu, nr 94, w: Źródła franciszkańskie: Pisma Świętego Franciszka. Źródła biograficzne Świętego Franciszka. Pisma Świętej Klary i źródła biograficzne. Teksty ustalające normy dla braci i sióstr od pokuty, red. R. Prajs, Z. Kijas, Kraków 2005, s. 508.

4I Por. Kodeks prawa kanonicznego, przekład polski zatwierdzony przez Konferencję Episkopatu, Poznań I984 [dalej: KPK], kan. 899 § oraz kan. 900 I.

42 Por. C. Niezgoda OFMConv, Św. Antoni z Padwy. Życie i nauczanie, Kraków 2002, s. 8I-82.

43 Por. C. Justi, Das Leben des Hl. Bonavenura gemalt von Herrera d. Ä. und Zurbaran, „Jahrbuch der Preussischen Kunstsammlungen” 4 (I883), s. I52-I53. 
Klamrą spinającą symbolikę tych obrazów są owalne obrazy ukazujące św. Bazylego i św. Tomasza z Akwinu. Bazyli wskazuje, że każdy musi składać ofiarę, będąc pojednanym z drugim, że winno się ją składać z uwielbieniem i że winna być ona składana w pokorze i uniżeniu ${ }^{44}$. Święty Tomasz wyjaśnia, że aby zaistniał sakrament, potrzebny jest kapłan, jego intencja, materia i wypowiedzenie słów konsekracji ${ }^{45}$.

Grupa omawianych tu trzech obrazów wskazuje kapłanowi na prawdę, że Bóg kocha człowieka i przez tę miłość udziela się człowiekowi oraz to, że człowiek winien odpowiadać swoją miłością na Bożą miłość, co prowadzi do głębokiego zjednoczenia Stwórcy i stworzenia. To dzięki temu zjednoczeniu każdy zasługuje na życie wieczne, o co prosi kapłan podczas mszy świętej, modląc się słowami Pierwszej modlitwy eucharystycznej: „Również nam, Twoim grzesznym sługom, ufającym w Twoje miłosierdzie, daj udział we wspólnocie z Twoimi świętymi Apostołami i Męczennikami [...] i wszystkimi Twoimi Świętymi; prosimy Cię, dopuść nas do ich grona nie z powodu naszych zasług, lecz dzięki Twojemu przebaczeniu"46.

Każdy kapłan, ubierając się do mszy świętej, miał na wysokościach swoich oczu nie tylko kryształowe lustra, by móc się w nich przeglądać, ale także owalne, małe przedstawienia apostołów i świętych franciszkańskich ${ }^{47}$. Dzięki nim przypominana jest prawda, że Bóg powołał go na urząd apostolski, by stawał się świętym Boga. Warto dodać, że na zwieńczeniach narożnych szaf, w których przechowuje się paramenty liturgiczne, znajdują się, w owalnych złotych ramach, wspartych na dekoracyjnie wykonanych wolutach, namalowane postacie ewangelistów ${ }^{48}$. Na tle całej dekoracji zakrystii jest to informacja, że Ewangelia jest punktem, do którego zmierzał Stary Testament, który opowiada o zbawczych dziełach Chrystusa i z którego wypływa „moc Boża ku zbawieniu dla każdego wierzącego” (por. Rz I, I6).

Kiedy kapłan przygotowujący się do celebracji liturgicznej odbędzie swoją odnawiającą, oczyszczającą i pouczającą podróż serca i ducha, kontemplując obrazy ścian ofiary, uniżenia i zjednoczenia, ubrany w odpowiednie szaty, może rozpocząc Świętą Boską Liturgię, urzeczywistniając wszystko

\footnotetext{
44 Por. Eucharystia pierwszych chrześcijan..., dz. cyt., s. 239.

45 Por. M. Tuta, Św. Tomasz z Akwinu - ,,Traktat o Eucharystii”, https://www.niedziela.pl/ artykul/386oi/nd/Sw-Tomasz-z-Akwinu---,,Traktat-o (II.06.20I9).

46 Z I modlitwy eucharystycznej.

47 Por. D. Biedrońska, Dokumentacja konserwatorska..., dz. cyt., s. 8.

$4^{8}$ Por. D. Biedrońska, Dokumentacja konserwatorska..., dz. cyt., s. 8.
} 
to, o czym rozmyślał, czego świadomość zyskiwał, co się w nim odnowiło. Będzie dokonywało się to bowiem: „Przez Chrystusa, naszego Pana, przez którego, Bóg, wszystkie te dobra ustawicznie stwarza, uświęca, ożywia, błogosławi i nam ich udziela’"49. Ostatnią czynnością bezpośredniego przygotowania do liturgii dawniej było obmycie rąk przez kapłana. Wychodząc z zakrystii, kapłan zatrzymywał się przy lawaterzu i obmywał ręce, modląc się Psalmem 25: „Lavabo inter innocentes manus meas: et circumdabo altare tuum, Domine: ut audiam vocem laudis, et enarrem universa mirabilia tua. Domine, dilexi decorem domus tuae, et locum habitationis gloriae tuae. $\mathrm{Ne}$ perdas cum impiis, Deus, animam meam, et cum viris sanguinum vitam meam: in quorum manibus iniquitates sunt: dextera eorum repleta est muneribus. Ego autem in innocentia mea ingressus sum: redime me et miserere mei. Pes meus stetit in directo: in ecclesiis benedicam te Domine. Gloria Patri" ${ }^{\prime}$. Warto nadmienić, że przykre jest to, a zarazem niedopuszczalne, że z wielu zakrystii usunięto lawaterze lub przerobiono je na szafki dla wzmacniacza nagłośnieniowego, na książki czy używa się ich jako wieszaka na ubrania.

Opisywana w artykule zakrystia bazyliki św. Franciszka w Krakowie, podobnie jak wiele innych istniejących w zabytkowych kościołach, zawstydza nas współczesnych, ukazując małą wrażliwość na sprawy święte. Wiele razy zauważa się, że kapłani wychodzą do ołtarza z marszu, bez przygotowania. A przecież Kodeks prawa kanonicznego jasno mówi: „Kapłan nie powinien opuszczać należytego przygotowania się przez modlitwę do sprawowania Eucharystii, a po jej zakończeniu złożenia Bogu dziękczynienia"ঙr. Budując kościół, kapłani niejednokrotnie chcą zorganizować współczesne zakrystie w sposób prosty, często także i bez staranności, wstawiając przypadkowe szafy, kredensy i inne nieprzystosowane meble mieszkaniowe. Trzeba pamiętać, że prosto nie oznacza niepobożnie, bez godności. Na podstawie niniejszego opracowania mogliśmy się przekonać, że zakrystia to przestrzeń niezwykle potrzebna kapłanowi i posługującym podczas liturgii w należytym przygotowaniu się do sprawowania świętych czynności. W dobie dzisiejszych

\footnotetext{
49 Z I modlitwy eucharystycznej.

$5^{\circ}$ „Umywam ręce moje na znak niewinności i obchodzę ołtarz Twój, Panie. By jawnie ogłaszać chwałę i rozpowiadać wszystkie cuda Twoje. Miłuję, Panie, siedzibę Twego domu i miejsce przybytku Twej chwały. Nie zabieraj z grzesznymi mej duszy i życia mego z mężami krwawymi. W ręku ich zbrodnia, a ich prawica pełna jest przekupstwa. Ja zaś postępuję w niewinności mojej. Wyzwól mnie, zmiłuj się nade mną. Na drodze równej stoi stopa moja. Na zgromadzeniach będę błogosławił Panu. Chwała Ojcu”.
}

${ }^{5} \quad$ KPK, kan. 909. 
rozkrzyczanych czasów i rzeczywistości, które pośrednio lub bezpośrednio mają wpływ na każdego człowieka, potrzebny jest zarówno czas i miejsce pomagające w wyciszeniu i przekierunkowaniu swojej uwagi, pragnień i myśli z profanum na sacrum. Zatem bardzo ważne jest zaplanowanie, zaprojektowanie i urządzenie współczesnych zakrystii w taki sposób, aby nie było to miejsce magazynowe z możliwością przyjęcia intencji mszalnej, ale miejsce wskazujące na to, że jest integralną częścią świątyni, w którym rozpoczyna się celebracja Ofiary Eucharystycznej już od przygotowania do niej.

Przedstawiona w niniejszym artykule tematyka miała na celu nie tylko uwrażliwić czytelnika na piękno dekoracji zakrystii bazyliki franciszkańskiej w Krakowie, lecz także wskazać na współczesną rzeczywistość rozumienia zakrystii kościelnej oraz wyrazić apel o powrót do właściwego pojmowania, projektowania, funkcjonowania części świętej przestrzeni świątyni, tak dziś zdewaluowanej. Wyjaśnienie symboliki omawianej przykładowej zakrystii może stanowić zachętę dla duszpasterzy, projektantów i budowniczych, by to ważne pomieszczenie nie było traktowane jako dodatek, ale jako integralna część kościoła, którą trzeba zaprojektować z wielką starannością oraz godnie i funkcjonalnie wyposażyć i udekorować, dzięki czemu będzie ona pomagać w zalecanym przez prawo kanoniczne należytym przygotowaniu do sprawowania Najświętszej Eucharystii.

\section{Bibliografia}

Augustyn św., De civitate Dei, Warszawa 1977.

Biedrońska D., Dokumentacja konserwatorska wystroju i wyposażenia zakrystii nowej w Bazylice OO. Franciszkanów pw. św. Franciszka z Asyżu przy Placu Wszystkich Świętych w Krakowie, Kraków 20II-20I2.

Chojnacki OCist M. P., Sacramentis ecclesiae communicare. Chrzest i eucharystia wedtug Bernarda z Clairvaux, Kraków 201 I.

Dawidowski T. A. ks., Katecheza o mszy świętej, http://sanctus.pl/index.php? grupa=I28\&podgru pa $=\mathrm{I} 46$ (20.04.20I8).

Eucharystia pierwszych chrześcijan. Ojcowie Kościoła nauczaja o Eucharystii, wybór i oprac. ks. M. Starowieyski, Kraków 2014.

Forstner D., Świat symboliki chrześcijańskiej, Warszawa $200 \mathrm{I}$.

Gogola OFMConv Z., Przybycie franciszkanów do Krakowa ma tle historii miasta, w: „Umiłowany od wszystkiego miasta". W 770. rocznice przy- 
bycia franciszkanów do Krakowa (I237-2007), red. ks. A. Bruździński, Z. Gogola, Kraków 2007, s. I6-I8.

Iwaszkiewicz-Wronikowska B., Kościót - aspekt architektoniczny, w: Encyklopedia katolicka, t. 9, Lublin 2002, kol. I027-I028.

Jan Paweł II, Encyklika Ecclesia de Eucharistia, Kraków 2003.

Justi C., Das Leben des Hl. Bonavenura gemalt von Herrera d. Ä. und Zurbaran, „Jahrbuch der Preussischen Kunstsammlungen” 4 (I883), s. I52-I66.

Kashchuk O., Księga Rodzaju jako źródto duchowej inspiracji w „Moralia in Iob” św. Grzegorza Wielkiego, „Biblica et Patristica Thoriuniensia” 4 (20II), s. 34I-460.

Kobielus S., Bestiarium chrześcijańskie. Zwierzęta w symbolice i interpretacji, Warszawa 2002.

Kodeks prawa kanonicznego, przekład polski zatwierdzony przez Konferencję Episkopatu, Poznań 1984.

Konieczny M., Światynia, w: Encyklopedia katolicka, t. I9, Lublin 2013, kol. 347-348.

Kubalska-Sulkiewicz K., Bielska-Łach M., Manteuffel-Szarota A., Stownik terminologiczny sztuk pięknych, Warszawa 2006.

Leksykon liturgii, oprac. B. Nadolski, Poznań 2006.

Leon-Dufour X., Stownik teologii biblijnej, Poznań 1994.

Lurker M., Stownik obrazów i symboli biblijnych, Poznań 1989.

Muczkowski J., Kościót św. Franciszka w Krakowie, Kraków I90I.

Niezgoda OFMConv C., Św. Antoni z Padwy. Życie i nauczanie, Kraków 2002.

Nowański J., Ars Eucharistica, Warszawa 2000.

Ogólne wprowadzenie do Mszatu rzymskiego, Poznań 2006.

Partyka W., Oratorium, w: Encyklopedia katolicka, t. I4, Lublin 20Iо, kol. 7-37.

Sinka CM T., Zarys liturgiki, Kraków 2006.

Solarz OFMConv F., Historia bazyliki, kru̇̇ganków i kaplic w zespole krakowskiego klasztoru franciszkanów, w: Krakowscy franciszkanie, red. B. Krużel, O. F. Solarz, Kraków 2009, s. 29, I02-I03.

Staszewski SChr J., Cudowne nawrócenie Wilhelma, księcia Akwitanii, przez św. Bernarda z Clairvaux, „Msza Święta” 2008 nr 3, s. 26-27.

Tomasz z Celano, Życiorys pierwszy Świętego Franciszka z Asyżu, nr 94, w: Źródła franciszkańskie: Pisma Świętego Franciszka. Źródta biograficzne Świętego Franciszka. Pisma Świętej Klary i źródła biograficzne. Teksty ustalajace normy dla braci i sióstr od pokuty, red. R. Prajs, Z. Kijas, Kraków 2005, s. 43I-550. 
Tuta M., Św. Tomasz z Akwinu - ,, Traktat o Eucharystii”, https://www.niedziela.pl/artykul/3860I/nd/Sw-Tomasz-z-Akwinu---,,Traktat-o (I2.06.20I9). Wielka encyklopedia PWN, t. 30, Warszawa 2005.

Zdanowski J., Akwamanile, w: Encyklopedia katolicka, t. I, Lublin I973, kol. 284 .

\section{SUMMARY}

\section{Vestry as a space of preparation for liturgy on the example of the church of St. Francis of Assisi in Krakow}

The topic of the following article is "Vestry as a space of preparation for liturgy on the example of the church of St. Francis of Assisi in Krakow". The author, besides historical issues concerning the vestry and the process of building the discussed Franciscan vestry, shows it as an example of the integral part of a church, used by the priest and acolytes for preparation for celebration of liturgy, as well as a place for storage of church equipment and liturgical books. The antique furnishings and decorations of a place that allow to prepare for the liturgy should help emphasizing the crucial role of celebration. The presented paper, besides theological interpretation, underlines the sanctity and dignity of a vestry, which always should present the high level of furnishings and decorations, what nowadays is misunderstood, underestimated and ignored when organizing the church both by architects and priests themselves. 
4. Uniwersytet Papiesk

(T) Jana Pawla II 